\title{
大阪府域に立地する超高層建物
}

\section{SUPER HIGH-RISE BUILDINGS IN OSAKA PREFECTURE}

\section{林 康裕 — $* 1$ 村瀬詩織 — $* 2$ \\ 杉野未奈 — * * 3 \\ キーワード \\ 超高層建物, データベース, 免震, 固有周期, 高さ}

Keywords:

Super high-rise building, Database, Base-isolation, Fundamental natural period, Height

\section{Yasuhiro HAYASHI — $* 1$ \\ Mina SUGINO $* 3$}

To predict the earthquake damage, we have constructed database of the super high-rise buildings in Osaka prefecture and identified the fundamental period of 32 super high-rise buildings by micro-tremor measurements. More than $20 \%$ of the super high-rise buildings are base-isolated, and more than $80 \%$ of the base-isolated buildings are condominium. The largest proportion of the building use was office before 2000. However, the construction of condominium has increased since 2001. After the 1995 Hyogo-ken Nambu earthquake the fundamental natural period has been short in Osaka. The fundamental natural period was about 1.1 to 1.3 times to that at the completion.

\section{1.はじめに}

筆者らは、南海トラフ沿いの巨大地震による長周期長時間地震 動および上町断層帯によるパルス性地震動による建物被害が懸念 される大阪市域を対象とし、評定シートが入手された超高層建物 を対象に、大振幅地震動に対する被害予測を行ってきた ${ }^{1) ほ か 。 そ ~}$ の結果、多くの建物が深刻な被害を経験する可能性があるため、 超高層建物の実態を把握し、懸念される被害様相をより正確に把 握する必要性を強く認識した。

本論文では、大阪府域全域の超高層建物を可能な限り網羅した データベースの構築を図るとともに、これまでほとんど報告の無 い使用時の微動計測を行って、現状分析を行う。まず、インター ネット情報に基づき、大阪府域の超高層建物のデータベースを作 成する。この際、建物の高さ、用途、階数、竣工年とともに、免 震建物か否かを特定する。次に、作成したデータベースを用いて、 建物の高さおよび用途別の建物棟数の変遷を免震・非免震別で明 らかにする。また、長周期地震動対策の対象地域（OS1、OS2、OS3） 別の建物棟数を示寸。最後に、32 棟の超高層建物の微動計測を行 い、竣工時との比較や竣工年による変化も含めて、1 次固有周期 の傾向を把握した結果について報告する。

\section{2. データベースの作成方法}

まず、超高層建物データのインターネット掲載サイト例えば2) 6)を 参考に、大阪府域における超高層建物のリストアップを行った。 緯度・経度はGoogle map 上で確認した。ただし、一般の掲載サイ トでは、概ね $60 \mathrm{~m}$ 以上の高さを有する建物が網羅されているわけ ではなく、漏れが少なくない。そこで、Google earthの立体写真 モデルと箱モデルを用いて、大阪府域全域において建物の高さを
1 棟 1 棟確認しながら追加抽出を行った。抽出された建物を図 1 に 示寸が、府域全体で 470 棟に達寸る。全 470 棟中、大阪市内に立 地しているのは 415 棟で、9 割弱に達する。しかも、図 1 よりも 明らかなように、大半は大阪市中心部の上町断層周辺に立地して いることが分かる。

建物の高さ、用途、階数、竣工年は、原則、インターネット情 報に基づいて収集した。しかし、高さが最高高さなのか軒高なの か、多くの場合に確認できなかった。そして、高さ自体が分から ない建物も多数存在した。高さが分からない場合には、原則とし て、Google earthの立体写真モデルより、建物頂部の標高と周辺 地盤の標高の差分を最高高さとして推定した。

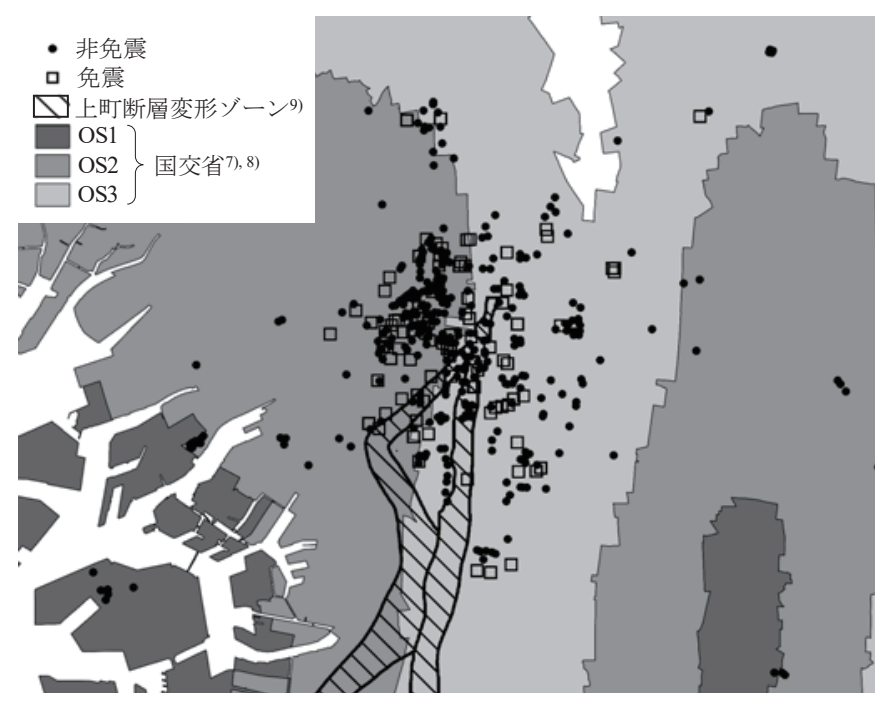

図 1 超高層建物立地位置

\footnotetext{
京都大学大学院 教授・工博

（干 615-8540 京都市西京区京都大学桂 C-2 棟 316 号室)

京都大学大学院 修士課程

京都大学大学院 助教・博士 (工学)
}

\footnotetext{
Prof., Dept. of Architecture and Architectural Eng., Kyoto Univ., Dr. Eng.

*2 Graduate Student, Dept. of Architecture and Architectural Eng., Kyoto Univ. Assist. Prof., Dept. of Architecture and Architectural Eng., Kyoto Univ., Dr. Eng.
} 
免震建物の特定は、一般社団法人 日本免震構造協会の超高層建 物一覧とともに、一般財団法人日本建築総合試験所や一般財団 法人 日本建築センターが公表している評定シートを基にデータ ベース化を試みた。しかし、共同住宅については、大阪府域に建 つ超高層建物の建設実態を把握する上で、無視できないほど多く の漏れがあった。しかも、その中には免震建物多く含まれていた ため、不動産売買・仲介サイトなどを基に、1 棟 1 棟、免震建物 か否かを確認した。

\section{3. 超高層建物の分析}

本章では、大阪府超高層建物データベースを用いて現状分析を 行う。

分析に先立ち、2 章でも述べたように、高さが最高高さなのか 軒高なのか、多くの場合に確認できていない。そこで、評定シー 卜より建物の最高高さが判明している 230 棟を用いて、2 章で求 めたデータベースの高さと評定シートの最高高さの比を求め、図 2 に示す。同図より、(高さ)/(最高高さ) は比較的低い建物を除き 1 となっており、データベースの高さは概称高高さと考えてよ いことが分かる。次に、同じく評定シートのデータを用いて、最 高高さと軒高の差を調べて、図 3 に示す。同図より、最高高さに 関係なく、0 13 m 程度に(最高高さ) - (軒高) が分布している。(最 高高さ)-(軒高)の平均値は $6.9 \mathrm{~m}$ 、標準偏差は $4.1 \mathrm{~m}$ であった。な お、オフィスの平均値は $6.2 \mathrm{~m}$ 、標準偏差は $4.3 \mathrm{~m}$ 、共同住宅の平 均值は $7.3 \mathrm{~m}$ 、標準偏差は $3.2 \mathrm{~m}$ となっている。すなわち、オフィ スの方が平均值は低いものの、ばらつきは大きいことが分かる。

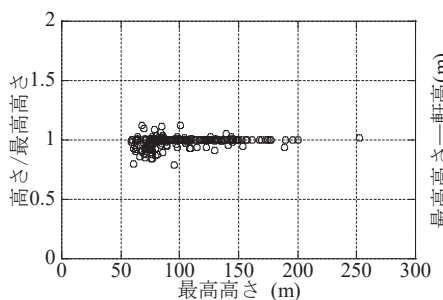

図 2 高さと最高高さの関係

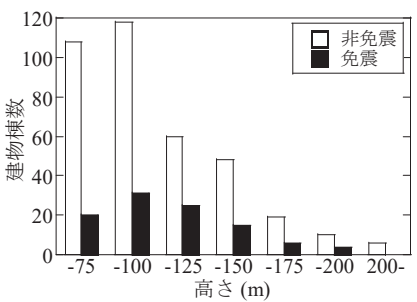

図 4 免震 ·非免震別の 高さ別の建物棟数

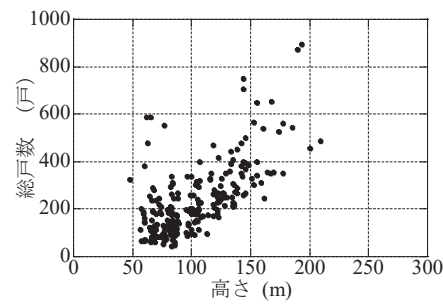

図 8 共同住宅の高さと総戸数

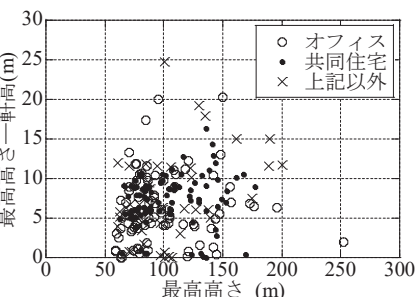

図 3 最高高さと軒高の関係

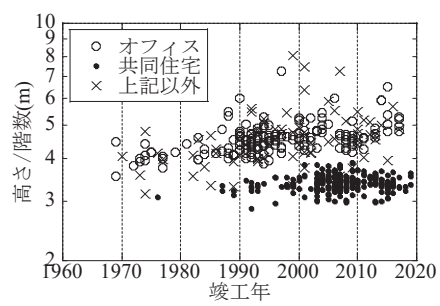

図 5 高さ／階数の変遷

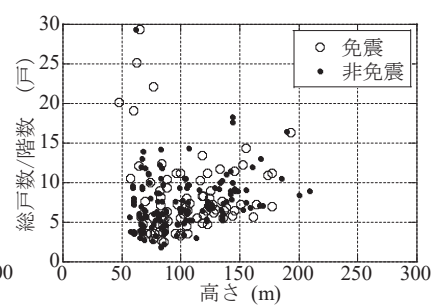

図 9 共同住宅の高さと 総戸数 /階数
次に、高さ別の建物棟数を免震と非免震で区別して図 4 に示寸。 免震建物は、全 470 棟中 101 棟と 2 割を超えるが、高さが $200 \mathrm{~m}$ を 超える建物はなく、9 割は $150 \mathrm{~m}$ 以下である。また、免震・非免 震に関係なく、半数以上が高さ $100 \mathrm{~m}$ 以下の建物である点にも注 意されたい。

最後に、平均階高の経年変化を考察するために、全 470 棟で (高 さ)/(階数)を竣工年別に図 5 に示す。共同住宅は $3 \sim 4 \mathrm{~m}$ で、オフィ スも含めてそれ以外は $4 \mathrm{~m}$ 以上となっている。竣工年が新しくな るにつれて、( 高さ)/( 階数) は増加する傾向にあり、共同住宅に 比べてオフィスの方が増加傾向は顕著である。なお、(高さ)/(階 数) が大きな建物は、鉄塔・劇場などを有していた。

次に、用途について考察する。図 6 に用途別の建物棟数の変遷 を示す。竣工年が 1995 年以前では、オフィスの建設が最も多かっ たが、それ以降は伸び悩んでいる。それに対して、共同住宅は 1980 年代前半から建設されはじめ、2010 年頃まで増加傾向にあった。 2011 年以降はやや減少しているものの、超高層建物に占める共同 住宅の建設割合が高いことに変わりはない。また、オフィスと共 同住宅の棟数を合計すると 392 棟になり、全 470 棟に対し 8 割以 上を占める。

一方、共同住宅の棟数変遷を図 7 に示す。同図中では、免震と 非免震を区別している。免震建物は2001 年以降に竣工している。 免震建物の 8 割以上を占める共同住宅を見ると、2006 年以降に竣 工した免震建物は、非免震建物とほぼ同数以上となっている。

また、超高層建物に損傷が生じた際の影響度を理解するための 一つの指標として、共同住宅の総戸数に着目した検討を行う。高 さと総戸数の関係を図 8 に示す。建物が高くなるにつれて総戸数 は増加するが、建物によってばらつきがあることが分かる。例え ば、高さ $150 \mathrm{~m}$ の建物では、総戸数は $300 \sim 600$ 戸の範囲に分布し ている。大阪府内の超高層共同住宅は 233 棟あるが、総戸数の総 和は54000 戸に達しょうとしている。このうち、大阪市内の超高 層共同住宅は約 180 棟で総戸数の総和は 40000 戸を超えている。

そこで、(総戸数)/(階数)を図 9 に示す。(総戸数)/(階数) は $2 \sim 15$ 戸に多くの建物が分布している。(総戸数)/(階数)が小さな建物

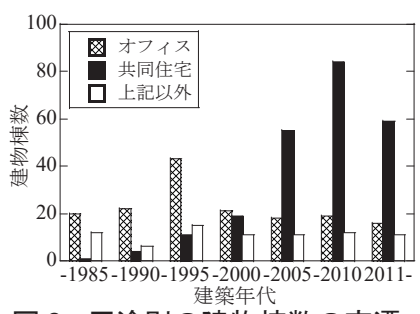

図 6 用途別の建物棟数の変遷

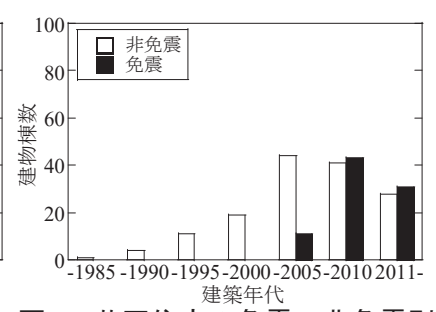

図 7 共同住宅の免震 ·非免震別 の建物棟数の変遷

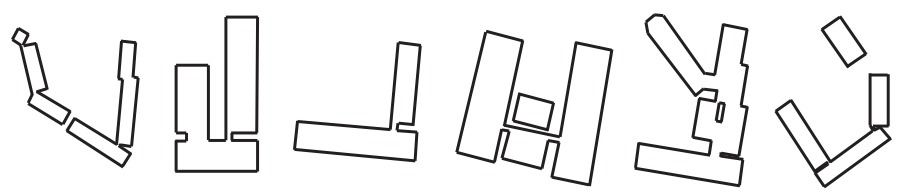

図 10 総戸数 /階数 $>19$ の建物配置 （右端のみ非免震、北は上、寸法は不統一） 
をサンプリングして個別に調べると、下記の傾向があった。

・ロビーやパーティールーム等の共用施設がある。

・平面が小さく 1 階あたりの面積が小さい。

・高層階住戸の面積が広い。

一方、( 総戸数)/ ( 階数) が 20 に近い共同住宅も存在している。(総 戸数 $) /($ 階数 $)$ が 19 より大きい 6 棟について、建物平面を模式的に 図 10 に示す。 6 棟とも高さ $80 \mathrm{~m}$ 未満であり、複数の上部構造で構 成され、お互いにエクスパンションジョイントで連結されてい た。注目される点としては、6 棟中 5 棟が免震建物であり、棟間 変形や礼じれ振動を、免震効果によって抑えていると考えられ る。ただし、過大な地震動が入力した場合には、擁壁と衝突し、 複雑な挙動を呈すると考えられる。

最後に、超高層建物の立地を図 1 に示寸 OS $1,2,3$ の 3 地域に分 けて分析する。国土交通省国土技術政策総合研究所及び国立研究 開発法人建築研究所は、高さが $60 \mathrm{~m}$ を超える建築物及び地上 4 階 建て以上の免震建築物（超高層建築物等）の長周期地震動対策と して「南海トラフ沿いの巨大地震による長周期地震動への対策」 に関わる技術資料・データ7,8)を作成し、平成 28 年 6 月 24 日付け 国住指第 1111 号で国土交通省住宅局から地方公共団体等の関係団 体あてに通知している。その中で、大阪地方では、設計時に構造 計算に用いた地震動の大きさを上回る可能性を基に、非常に高い 地域 (OS 1$)$ 、高い地域 (OS2)、ある地域 (OS 3$)$ の 3 地域に分割 して検討用の地震動が示されている。各ゾーンの擬似速度応答ス ペクトルは、告示スペクトルの 1 倍、1.5 倍、2 倍を基本として、 簡略化して定められている。

全 470 棟中、地域指定が無い建物は 16 棟、OS 1 は非免震の 7 棟 にしか過ぎない。従って、図 1 に示すように大半は OS 2 と OS 3 地 域に建っており、両者に立地している建物はOS 2 で 208 棟、OS 3 で239 棟と棟数に大差はない。

\section{4. 超高層建物の固有周期}

竣工時の 1 次固有周期については、数多く報告されている ${ }^{10,11)}$ 。本
論文では、使用時における 1 次固有周期の実態把握を目的として、超 高層建物の微動計測を行った。対象建物の立地地域は、大阪圈 17 棟、 東京圈 13 棟、その他地域 2 棟の合計 32 棟である。構造種別は、 $\mathrm{SRC}$ 造か $\mathrm{RC}$ 造を $\mathrm{RC}$ 造系、 $\mathrm{S}$ 造か $\mathrm{CFT}$ 造は $\mathrm{S}$ 造系とすると、 $\mathrm{S}$ 造系は 26 棟、 $\mathrm{RC}$ 造系は 6 棟であった。東京圈で計測した建物は全て $\mathrm{S}$ 造系 であり、 $\mathrm{RC}$ 造系は大阪圈に 4 棟、その他地域に 2 棟立地している。 $\mathrm{RC}$ 造系のうち、共同住宅は 3 棟である。計測は、展望スペースや 休䅨・食事スペースなど、一般に開放されたスペースで行った。 計測のほとんどは、高精度・小型の加速度計 1 台（水平 2 成分と 上下成分）を用いて行った。計測位置は、必ずしも建物の最上階 周辺ではなく、中間階でも行っている。38 階建ての 4 階での計測 でも、1 次固有周期が同定可能な場合もあった。

計測波形には、下記の処理を行って 1 次固有周期を同定してい る。本論文では、建物の固有周期が長い方向を $\mathrm{x}$ 方向、短い方向 をy 方向として 2 方向の 1 次固有周期を算出する。まず、 6 次のバ タワースフィルタを用いて、ローパスフィルターとハイパスフィ ルターをかけ、 $0.07 \mathrm{~Hz}$ から $5 \mathrm{~Hz}$ の信号を抽出する。計測波形から 40.96 秒ずつずらしながら、163.84 秒毎に分割した波形を作成し、 分割波形毎にバンド幅 $0.07 \mathrm{~Hz}$ のParzen ウィンドウをかける。そ して、それぞれのフーリエ変換值を算出した後、平均化処理を 行ってフーリエスペクトルを算出した。1 次固有周期は、建物高 さに対応した周波数帯域のピーク振動数から特定した。4 階建て の複合ビル（低層部は 13 階までで、14 階で大きくセットバック している）の 15 階で得られた計測結果を図 11 に示す。このよう に、ほとんどの場合、フーリエスペクトルのピークは明瞭であっ た。そのため、特別な工学的判断を加えず、最も長周期側のピー ク周期を 1 次固有周期と同定した。

まず、計測した建物のうち、評定シートに記載されていた固有 周期（設計固有周期）と微動計測によって同定された（使用時） 固有周期の関係を図 12 に示す。なお、計測した建物には、超高層 免震建物が含まれている。その場合には、基礎固定時の値を設計 固有周期として示している。設計固有周期は微動による固有周期

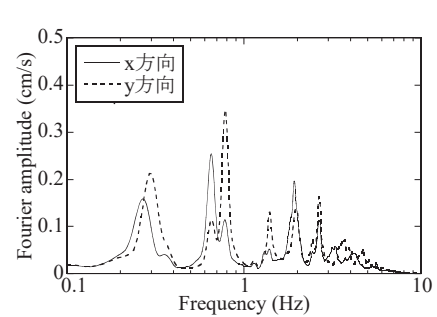

図 11 フーリエスペクトル例

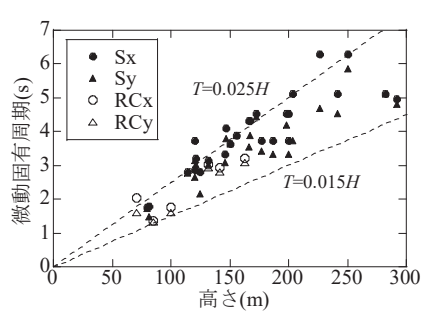

図 14 高さと微動固有周期の関係

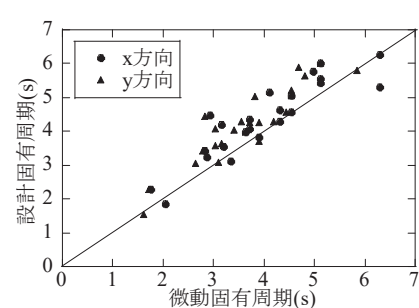

図 12 設計固有周期と 微動固有周期の関係

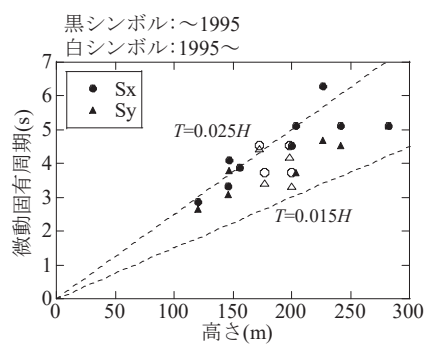

(a) 東京圈

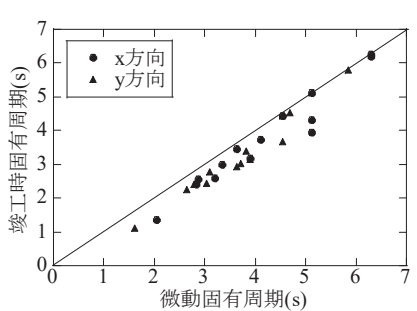

(a) 竣工時と使用時の比較

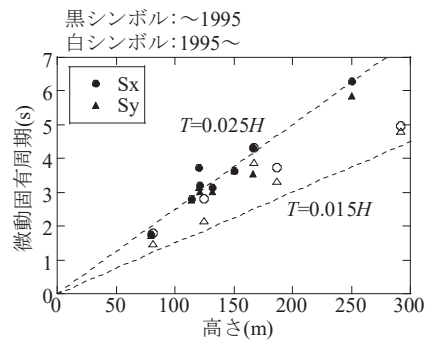

(b) 大阪府

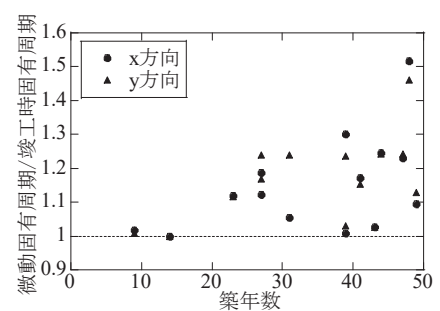

(b) 築年数と固有周期の増加割合

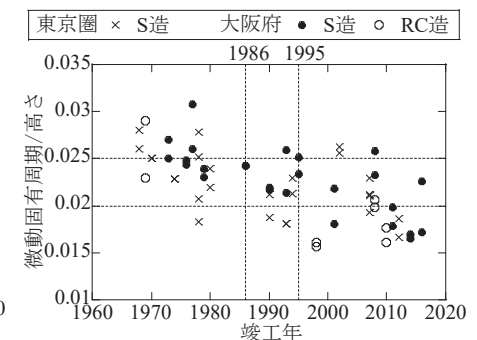

図 16 微動固有周期／高さの変遷

図 15 高さと微動固有周期の関係（東京圏と大阪府の比較） 
よりもやや長めではあるが、一部の例外を除いて両者は概ね対応 していることが分かる。次に、竣工時に計測されていた微動固有 周期 10) と筆者らが微動計測して得られた固有周期の関係を図 $13(\mathrm{a})$ に示す。竣工時に比べてほとんどの建物で固有周期が長周期化し ていることが分かる。竣工後の築年数と竣工時に対する固有周期 比の関係を図 13 (b) に示寸。竣工後 20 年以上が経過した建物で得 られた結果が多いが、竣工時に計測された微動固有周期に比べて 1 3 割程度長周期化している建物が多いことが分かる。中には 5 割程度長周期化している R C 造系建物もあった。

図 14 に、高さ $H$ と微動計測から得られた固有周期の関係を、上 部構造の構造種別別に示す。ここで、本章での高さ $H$ は、評定シー トで軒高が確認できた建物は軒高とし、軒高が確認できなかった 6 棟の建物は最高高さとしている。従って、軒高に比べるとやや 大き目の值となっている。同図では、SRC 造か RC 造を RC、S 造 か CFT 造を $\mathrm{S}$ と表記している。そして、添え字の $\mathrm{x}, \mathrm{y}$ は、それぞ れ、固有周期が長い方向と、短い方向を表している。図 14 より、 $\mathrm{RC}$ 造系に比べて、S 造系の固有周期の方が長めであるが、いずれ も、概称 $T=0.015 H \sim 0.025 H$ の範囲に分布していることが分かる。 次に、立地地域を東京圈と大阪府の地域別に分けて、 $\mathrm{S}$ 造系の 高さと微動計測から得られた固有周期の関係を図 15 に示す。構造 建物の設計においては、1970 年代では最大加速度を用いてレ心゙ル 設定をされていたが、1986 年 ${ }^{12)}$ 以降最大速度を指標としたレベル 設定が用いられている。レベル 2 地震動の最大速度は、 $50 \mathrm{~cm} / \mathrm{s}$ と されていたが、大阪では $40 \mathrm{~cm} / \mathrm{s}$ とされることが多かった。しかし、 大阪府では兵庫県南部地震の発生に伴い、レベル 2 地震動の最大 速度が $50 \mathrm{~cm} / \mathrm{s}$ に変更されている。このような歴史的背景を踏まえ て、固有周期の変化について考察する。まず、図 15 では、東京圈 においては、兵庫県南部地震を契機として、固有周期と高さの関 係に顕著な変化は見られない。しかし、大阪府においては、1995 年以前に竣工した建物には概水 $T=0.025 H$ の関係があったのに対 して、1995 年以降の竣工建物には有意な短周期化の傾向が見られ る。最後に、図 16 に竣工年と(微動固有周期 $T$ )/ ( 高さ $H$ ) の関係を 示す。竣工年が新しくなると、明らかに固有周期の短周期化が見 られる。 RC 造系は計測事例が少ないが、1995 年以降の竣工建物 では $T / H=0.015 \sim 0.02$ と 造系に比べて短周期であることが分か る。 $\mathrm{S}$ 造系について見ると、概补、1986 年以前の竣工建物は $T / H$ $=0.02 \sim 0.03$ で、1986 年 $\sim 1995$ 年の竣工建物は $T / H=0.017 \sim 0.025$ 、 1995 年以降の竣工建物は $T / H=0.015 \sim 0.025$ となっている。この ように、竣工年が新しくなるにつれて短周期化の傾向があるもの の、前述のように、1995 年以前では東京圈の方が大阪に比べて短 周期であるのに対して、1995 年以降では両地域に顕著な差は見ら れなくなっている。

\section{5. まとめ}

本論文では、大阪府域に立地する超高層建物の地震被害を予測 す心゙く、殆どの超高層建物を網羅したデータベースを構築し、現 状分析を行った。また、超高層建物の微動計測を行い、建物使用
時の 1 次固有周期の実態把握を行った。本計測結果は、既往の超 高層建物の振動計測データ 10,11$)$ と異なり、減衰定数の同定は行っ ていないが、 1 次固有周期の建設年代別の比較や竣工後の経年変 化を考察している点に大きな特徵がある。得られた結果を以下に 示す。

1) データベース化した超高層建物 470 棟のうち 101 棟が免震建物 であり、全体の 2 割以上を占める。また、免震建物のうち 8 割 以上は共同住宅であり、2006 年以降の共同住宅については、非 免震建物より免震建物の方が多くなっている。

2) 主用途別の建物棟数の変遷では、竣工年が 1995 年以前はオフィ スが増加傾向にあるが、それ以降は停滞している。一方、1980 年代前半からは共同住宅が増加しており、全棟数に占める共同 住宅の割合が最も大きい。このうち、大阪市内の共同住宅は約 180 棟で総戸数の総和は 40000 戸を超えている。

3 ) 超高層建物のほとんどは、長周期地震動対策の対象地域の内、 OS 2、OS3に立地している。また、両地域に立地している建物 棟数に大差はない。

4) 築年数 20 年程度以上の超高層建物では、竣工時に実施された 微動計測結果よりも多くの建物で固有周期が $1 \sim 3$ 割程度長周 期化しており、概ね、設計固有周期に対応していた。大阪府の 超高層建物では、兵庫県南部地震を契機として地震荷重が増加 し、明瞭な短周期化傾向が見られた。結果として、超高層建物 の固有周期は、 $T=0.015 H \sim 0.025 H$ の範囲に分布している。た だし、H は建物高さである。

\section{参考文献}

1) 木村友香, 岡沢理映, 関口春子, 林康裕 : 大阪市域を対象としたパルス性 地震動に対する超高層建物群の被害予測（その1，2），日本建築学会大会 学術講演梗概集, pp.197-200, 2014.9.

2) 超高層ビル・超高層マンションの『BLUE STYLE COM』: 大阪府の超高層 ビルデータベース, http://www.blue-style.com/area/osaka/ (参照 2017.9.8)

3) ウィキペディア：大阪府の超高層建築物・構築物の一覧, https://ja. wikipedia.org/wiki/ 大阪府の超高層建築物・構築物の一覧（参照 2017.9.8）。

4) 大阪 at night - 大阪の夜景 - : 大阪府の高層ビル, http://www.osakanight.com/ skyscrapers/（参照 2017.9.8）

5) 超高層ビルとパソコンの歴史 : 大阪市・超高層ビルデータベースランキン グ一覧, http://www.eonet.ne.jp/ building-c/oosaka/builoosaka.htm（参照 2017.9.8）

6) OSAKA ビル景 : http://bb-building.net/（参照 2017.9.8）

7) 国土交通省：超高層建築物等における南海トラフ沿いの巨大地震による長 周期地震動への対策について, http://www.mlit.go.jp/jutakukentiku/build/ jutakukentiku_house_fr_000080.html (参照 2017.9.8)

8) 国土交通省住宅局建築指導課長: 平成 28 年 6 月 24 日国住指第 1111 号 超 高層建築物等における南海トラフ沿いの巨大地震による長周期地震動対策 について (技術的助言), http://www.mlit.go.jp/common/001136168.pdf (参照 2017.9.8)

9) 地震調查研究推進本部 : 上町断層帯における重点的な調查観測 平成 $22 \sim$ 24 年度成果報告書, http://www.jishin.go.jp/database/project_report/uemachi_jutenh24/（参照 2017.9.8）.

10) 実測減衰データベース ダウンロード, http://news-sv.aij.or.jp/kouzou/s7/ d1.htm（参照 2017.9.8）

11) 日本建築学会 : 建築物の隇衰, 2000.10 .

12) 日本建築センター：ビルディングレター, 高層建築物の動的解析用地震動 について, pp.49-50, 1986.6.

[2018 年 2 月 6 日原稿受理 2018 年 4 月 16 日採用決定］ 